\title{
Dual transcriptomics of virus-host interactions: comparing two Pacific oyster families presenting contrasted susceptibility to ostreid herpesvirus 1
}

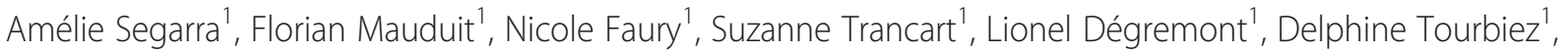

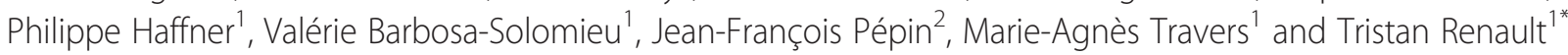

\begin{abstract}
Background: Massive mortality outbreaks affecting Pacific oyster (Crassostrea gigas) spat in various countries have been associated with the detection of a herpesvirus called ostreid herpesvirus type 1 (OsHV-1). However, few studies have been performed to understand and follow viral gene expression, as it has been done in vertebrate herpesviruses. In this work, experimental infection trials of C. gigas spat with OsHV-1 were conducted in order to test the susceptibility of several bi-parental oyster families to this virus and to analyze host-pathogen interactions using in vivo transcriptomic approaches.
\end{abstract}

Results: The divergent response of these oyster families in terms of mortality confirmed that susceptibility to OsHV-1 infection has a significant genetic component. Two families with contrasted survival rates were selected. A total of 39 viral genes and five host genes were monitored by real-time PCR. Initial results provided information on (i) the virus cycle of OsHV-1 based on the kinetics of viral DNA replication and transcription and (ii) host defense mechanisms against the virus.

Conclusions: In the two selected families, the detected amounts of viral DNA and RNA were significantly different. This result suggests that Pacific oysters are genetically diverse in terms of their susceptibility to OsHV-1 infection. This contrasted susceptibility was associated with dissimilar host gene expression profiles. Moreover, the present study showed a positive correlation between viral DNA amounts and the level of expression of selected oyster genes.

Keywords: Interactions, Ostreid herpesvirus 1, Gene expression, Susceptibility, Crassostrea gigas

\section{Background}

Ostreid herpesvirus type 1 (OsHV-1), the causative agent of major economic losses in the Pacific oyster industry, is a member of the family Malacoherpesviridae from the order Herpesvirales [1,2]. It was in particular identified as the main cause of the massive mortality outbreaks of C. gigas spat recently reported in Europe, Australia and New Zealand $[3,4]$.

Within this context, the control of OsHV-1 infection is considered as a key element to maintain the competitiveness and to increase the sustainability of oyster industry.

\footnotetext{
* Correspondence: Tristan.Renault@ifremer.fr

'Ifremer (Institut Français de Recherche pour l'Exploitation de la Mer), Unité Santé Génétique et Microbiologie des Mollusques (SG2M), Laboratoire de Génétique et Pathologie des Mollusques Marins (LGPMM), Avenue de Mus de Loup, 17390 La Tremblade, France

Full list of author information is available at the end of the article
}

However, Pacific oysters as well as all other marine molluscs have unique features in terms of health management [5]. Not only do they live in open marine waters, directly exposed to pathogen infection but they also lack an adaptive immune system. Vaccination is therefore not an option to protect them against virus infection. As a consequence, most strategies currently used for other farmed animal species (e.g., cattle, fish) cannot be directly applied to Pacific oysters. One of the few applicable and promising approaches to limit the harmful effect of pathogens in oyster production is, selective breeding [6].

In animal populations, susceptibility to virus infection and the modulation of disease progression display interindividual variability [7-9]. The study of host factors that control disease susceptibility relies on the multi-approach analysis of individuals demonstrating a differential response 
to OsHV-1 exposure/infection. This type of data will facilitate the identification of new targets with the potential to be integrated in innovative selection strategies. Genes that confer resistance to OsHV-1 may indeed be revealed by combining the "top-down" QTL approach to identify target genomic regions, with "bottom-up" transcript profiling. A QTL analysis for OsHV-1 DNA detection and quantification that was previously performed on five $\mathrm{F}_{2}$ full-sib families highlighted the relevance of further studying their respective genetic controls $[10,11]$.

Oyster gene expression has already been studied [12-14], particularly since the oyster genome was sequenced [15]. However, most studies relied on the use of oysters collected in the field which are subjected to multiple stressors and pathogens $[12,13,16,17]$. In addition, only three studies reported OsHV-1 gene expression while the OsHV-1 cycle has never been described at a molecular level [18-20].

The aim of our study was to determine the genetic basis of differential susceptibility to virus infection among Pacific oysters. To overcome the variability of environmental factors, we reproduced the viral infection under controlled laboratory conditions. Sixteen Pacific oyster families were initially challenged with the virulent variant of OsHV-1, $\mu$ Var [21]. Survival rates were evaluated five days postinjection and used as a measure of their susceptibility to OsHV-1. In a second step, two Pacific oyster families with contrasted susceptibility were selected for transcript profiling of 39 virus and five oyster immune related genes.

\section{Results}

Screening Pacific oyster families for OsHV-1 susceptibility Two independent experimental infection trials were performed to strengthen the results in terms of survival rates of the 16 bi-parental families of Pacific oysters that were challenged. After infection, mortality was monitored daily for a period of 120 hours. Control batches systematically displayed 100\% survival rates. Results showed that susceptibility to OsHV-1 was different among the tested oyster families (Figure 1). Survival rates were $2 \pm 1.6 \%$ for family "A" and $90 \pm 4.5 \%$ for family "P" 120 hours post infection (hpi) (Table 1). Based on their survival rates and Wilcoxon test $(\mathrm{p}>0.05)$ (Table 1$)$, families $\mathrm{A}$ and $\mathrm{P}$ were selected to represent the most extreme performances in terms of susceptibility to OsHV-1. A typifies the extremely sensitive family and $\mathrm{P}$ the less sensitive family with regard to infection by OsHV-1 (Figure 1).

\section{Comparing two families with contrasted susceptibility to OsHV-1 infection}

The respective mean survival rates of families $\mathrm{A}$ and $\mathrm{P}$ were $37 \%$ and $95 \%$ at 48 hpi and $0 \%$ and $90 \%$ at 72 hpi (KaplanMeier, Figure 2). At later time points, family A was entirely dead whereas the survival rate was stable $(89.5 \% 72 \mathrm{~h}$ and 144 hpi) for family P (Figure 2). As indicated previously, the survival rate was $100 \%$ for oyster controls.

Virus DNA was initially detected at $4 \mathrm{hpi}$ for family A and 12 hpi for family P (Figure 3). The mean amounts of viral DNA increased gradually during the course of infection in family A until all oysters died, whereas it increased up to $72 \mathrm{hpi}$ and decreased until $144 \mathrm{hpi}$ in family P (Figure 3). Viral DNA amounts were overall lower in family $\mathrm{P}$ than in family A (Figure 3 ). In family A, individual amounts of OsHV-1 DNA ranged from 0 to $3.2 \times 10^{\circ}, 0$ to $1.7 \times 10^{1}, 0$ to $2.8 \times 10^{3}$, and $1.2 \times 10^{1}$ to $9.5 \times 10^{6}$ viral DNA copies per ng of total DNA at 4 hpi, 8 hpi, 12 hpi and 26 hpi, respectively. In family P,

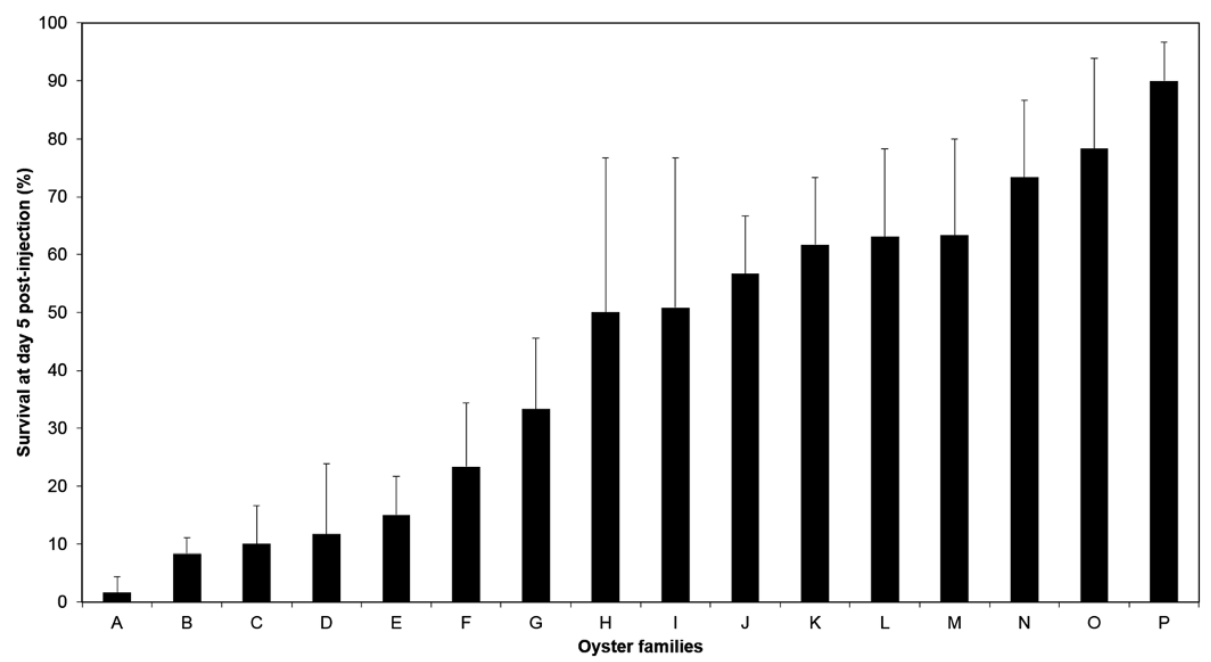

Figure 1 Survival of 16 families of Crassostrea gigas oysters at 120 hours post infection during OsHV-1 challenges. Two assays were conducted in triplicates for each family $(n=60)$. For all 16 families, $100 \%$ of survival was reported among negative controls injected with $100 \mu \mathrm{L}$ of artificial seawater. 
Table 1 Survival rates of the challenged families and identification of groups of families with significantly distinct performances

\begin{tabular}{|c|c|c|c|c|c|c|c|}
\hline \multirow[t]{2}{*}{ Families } & \multirow[t]{2}{*}{ Wilcoxon test $(p<0.05)$} & \multicolumn{6}{|c|}{ Survival post infection (\%) } \\
\hline & & $\overline{O \text { hpi }}$ & $24 \mathrm{hpi}$ & $48 \mathrm{hpi}$ & $72 \mathrm{hpi}$ & $96 \mathrm{hpi}$ & $120 \mathrm{hpi}$ \\
\hline$A$ & $\mathrm{a}$ & 100 & 100 & $32( \pm 9.5)$ & $15( \pm 5)$ & $3( \pm 3.3)$ & $2( \pm 1.6)$ \\
\hline B & $a b$ & 100 & 100 & $53( \pm 8)$ & $25( \pm 4.3)$ & $8( \pm 1.6)$ & $8( \pm 1.6)$ \\
\hline C & $b c$ & 100 & 100 & $47( \pm 7.1)$ & $12( \pm 4)$ & $10( \pm 3.6)$ & $10( \pm 3.6)$ \\
\hline D & $b c$ & 100 & 100 & $78( \pm 9.8)$ & $25( \pm 7.6)$ & $15( \pm 6.1)$ & $12( \pm 6.5)$ \\
\hline $\mathrm{E}$ & $b c$ & 100 & 100 & $47( \pm 5.6)$ & $28( \pm 6.5)$ & $17( \pm 3.3)$ & $15( \pm 3.4)$ \\
\hline $\mathrm{F}$ & $b c$ & 100 & 100 & $97( \pm 5.4)$ & $75( \pm 11.4)$ & $57( \pm 11.9)$ & $33( \pm 6.5)$ \\
\hline G & c & 100 & 100 & $67( \pm 7.1)$ & $47( \pm 9.5)$ & $37( \pm 11.1)$ & $33( \pm 8)$ \\
\hline $\mathrm{H}$ & $\mathrm{cd}$ & 100 & 100 & $92( \pm 5.4)$ & $80( \pm 7.3)$ & $60( \pm 12.1)$ & $50( \pm 13.2)$ \\
\hline । & def & 100 & 100 & 100 & $90( \pm 3.3)$ & $80( \pm 4)$ & $70( \pm 4.9)$ \\
\hline J & de & 100 & 100 & $88( \pm 6.3)$ & $66( \pm 8.5)$ & $62( \pm 8.9)$ & $60( \pm 7.9)$ \\
\hline K & def & 100 & 100 & 100 & $78( \pm 4.9)$ & $72( \pm 7)$ & $65( \pm 6)$ \\
\hline$L$ & de & 100 & 100 & $90( \pm 6.3)$ & $67( \pm 10.5)$ & $62( \pm 10.6)$ & $57( \pm 8.8)$ \\
\hline M & ef & 100 & 100 & 100 & $70( \pm 4.5)$ & $63( \pm 4.8)$ & $52( \pm 8.7)$ \\
\hline N & ef & 100 & 100 & $88( \pm 3)$ & $80( \pm 5.8)$ & $75( \pm 7.6)$ & $73( \pm 6.7)$ \\
\hline $\mathrm{O}$ & $d f$ & 100 & 100 & 100 & $90( \pm 3.6)$ & $73( \pm 8.7)$ & $73( \pm 8.7)$ \\
\hline P & g & 100 & 100 & 100 & $95( \pm 5)$ & $92( \pm 4.8)$ & $90( \pm 4.5)$ \\
\hline
\end{tabular}

Groups based on the daily monitoring of mortality during 120 hours post infection (Wilcoxon test). Lowercase letters design a family group significantly different from all the others. All families were tested by pairs and several groups were identified.

individual amounts of OsHV-1 DNA ranged from 0 to $1.4 \times 10^{1}, 0$ to $1.3 \times 10^{5}, 0$ to $9.1 \times 10^{5}$ and 0 to $7.2 \times 10^{2}$ viral DNA copies per ng of total DNA at $12 \mathrm{hpi}, 26 \mathrm{hpi}$, $72 \mathrm{hpi}$ and $144 \mathrm{hpi}$, respectively. No virus DNA was detected in oysters injected with artificial seawater.

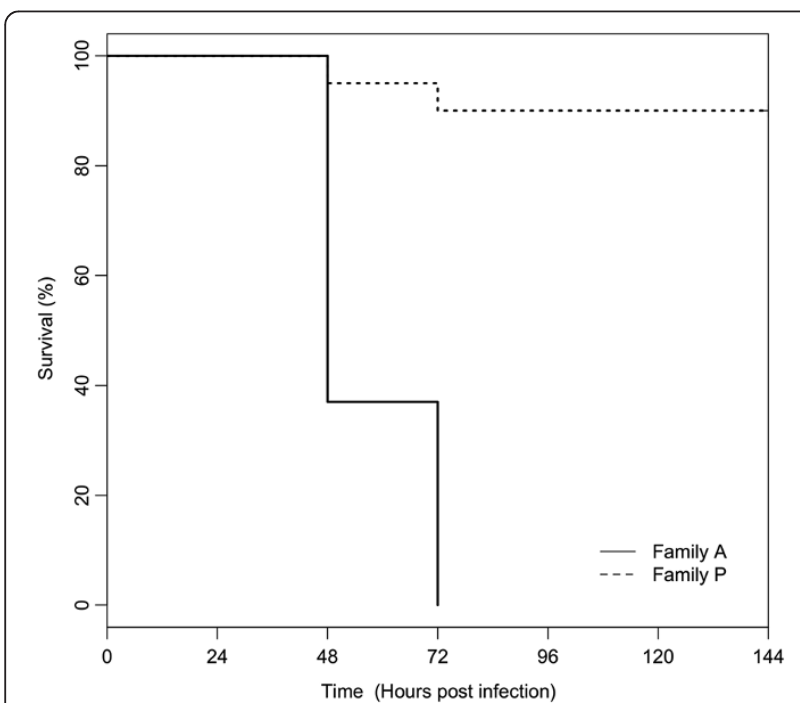

Figure 2 Kaplan-Meier survival curves of two families of Crassostrea gigas during infection with OsHV-1. For the third experiment, one tank was used $(n=20)$. For the two families, 100\% of survival was reported among negative controls injected with $100 \mu \mathrm{L}$ of artificial seawater.

\section{Detection and expression of OsHV-1 genes in A and $\mathrm{P}$ families}

The level of expression in mantle tissue of 39 OsHV-1 genes was studied in both families (A and $\mathrm{P}$ ) by realtime PCR. These particular genes were selected based on literature data and/or their specific function $[1,13]$. The full list of OsHV-1 genes is available in Segarra et al. [18]. Normalized expression levels were calculated for each individual at each time point in both families. Two heatmaps were generated (Figure $4 \mathrm{a}$ and b). The most striking finding was the existence of different levels of gene expression between both families. All 39 ORFs were significantly over-expressed (Wilcoxon test, $\mathrm{p}<$ 0.05 ) in family A in comparison to family $\mathrm{P}$, particularly at 26 hpi $(F=1.5$ and $F=-1$, respectively). Moreover, initial detection of virus transcripts was performed as early as $4 \mathrm{hpi}$ in family A but did not occur until $12 \mathrm{hpi}$ in family P. In family P, expression levels peaked at 26 and 72 hpi before and decreased at $144 \mathrm{hpi}$. Differences in terms of expression levels were observed between individuals belonging to the same family and collected at identical time points. No viral transcript was detected at 0 hpi in either family.

Virus transcripts were grouped by the euclidean method to produce a dendrogram comparing the expression levels of all 39 ORFs (Figure $4 \mathrm{a}$ and b). Three clusters were observed for each family. Cluster 1 corresponds to high expression levels, regrouped 17 genes in family A and 19 


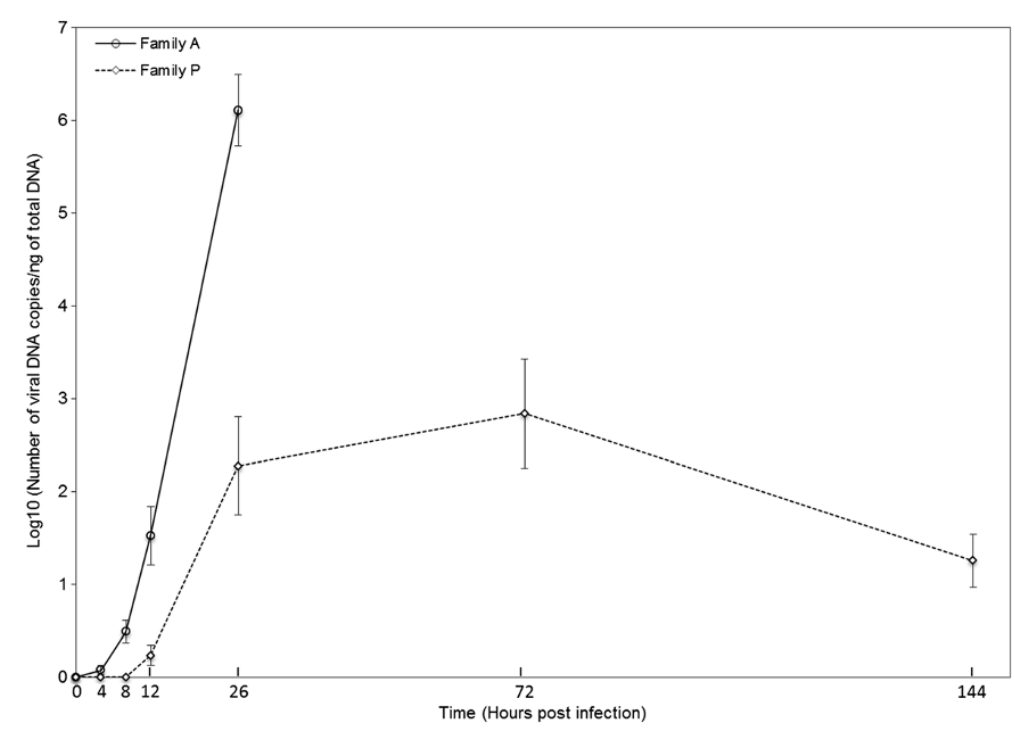

Figure 3 Virus DNA detection curves by real time quantitative PCR in oyster from families A and $P$ after injection OsHV-1 (average $n=12$ ). In both families, a result of 0 DNA copies/ng of total DNA was reported for negative controls injected with $100 \mu \mathrm{L}$ of artificial seawater. Error bars represent \pm standard deviation.

genes in family $\mathrm{P}$ (Figure 4a and b). Cluster 2, with medium expression levels, comprised 19 genes in family A and 18 genes in family P, (Figure $4 \mathrm{a}$ and $\mathrm{b}$ ). The third and last cluster included three genes in family $\mathrm{A}$ and two genes in family $\mathrm{P}$ and was characterized by low expression levels (Figure 4a and b). Significant differences were observed between the three clusters $(\mathrm{C} 1, \mathrm{C} 2$ and $\mathrm{C} 3)$ in family A whereas no difference was detected in family $\mathrm{P}$ for these clusters (Kruskal-Wallis and Dunn's tests, $\mathrm{p}<0.05$ )
(Figure 5). However, $82 \%$ of the analyzed ORFs (32/39) were classified in the same cluster in both families: 15 genes belonged to cluster 1 (ORF 4, ORF 16, ORF 27, ORF 42 , ORF 43 , ORF 72 , ORF 75 , ORF 81 , ORF 87 , ORF 96, ORF 97, ORF 99, ORF 111, ORF 117, ORF 124); 15 genes to cluster 2 (ORF 7, ORF 20, ORF 34, ORF 47, ORF 54, ORF 64 , ORF 68 , ORF 77, ORF 81 , ORF 86 , ORF 100 , ORF 103, ORF 106, ORF 109, ORF 118) and two genes to cluster 3 (ORF 41, ORF 67). In both families, three viral

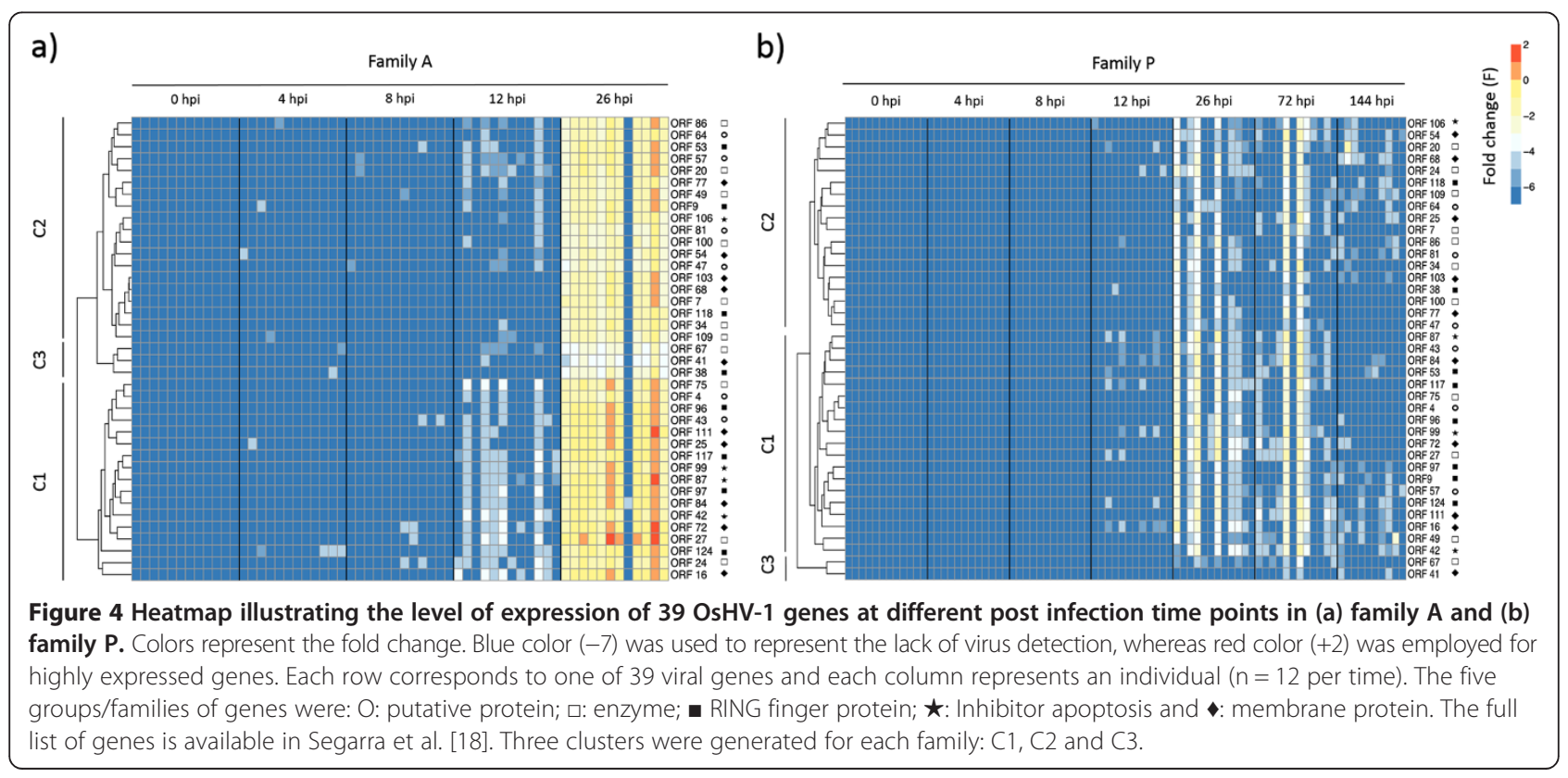




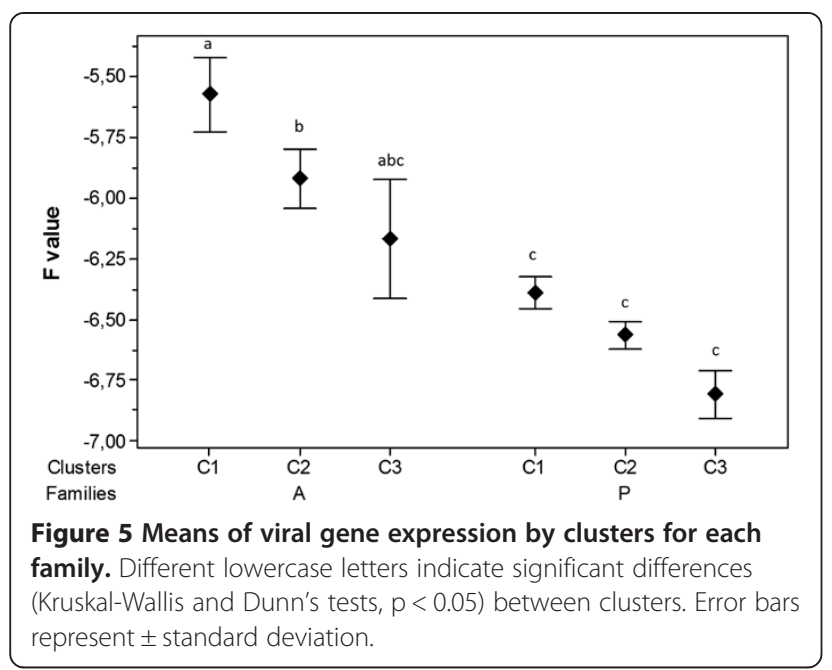

inhibitor of apoptosis (IAP) genes (ORF 42, ORF 87 and ORF 99) out of the four IPAs that were analysed pertained to cluster 1 (Figure $4 \mathrm{a}$ and $\mathrm{b}$ ).

\section{Relative quantification of host gene expression in A and P families}

In the third experiment, a significant increase or decrease in mRNA levels was reported for IFI44, MyD88, IAP and IkB2 at several times post injection in challenged oysters from both families as compared with negative controls (Figures 6 and 7). In family A, IFI44 gene expression was up-regulated at $26 \mathrm{hpi}$ in infected oysters $(\mathrm{R}=24.1)$ compared to control oysters $(\mathrm{R}=1.3)$ $(\mathrm{p}<0.05)$. In family P, IFI44 transcript level (Figure 6) was up-regulated from $26 \mathrm{hpi}$ to $72 \mathrm{hpi}$ and $144 \mathrm{hpi}$ $(\mathrm{R}=10.2, \mathrm{R}=33.7$ and $\mathrm{R}=47.3$, respectively) comparatively to the control $(R=2, R=1.3$ and $R=1.2$, respectively) $(\mathrm{p}<0.05)$. In family $\mathrm{A}$, the expression level of

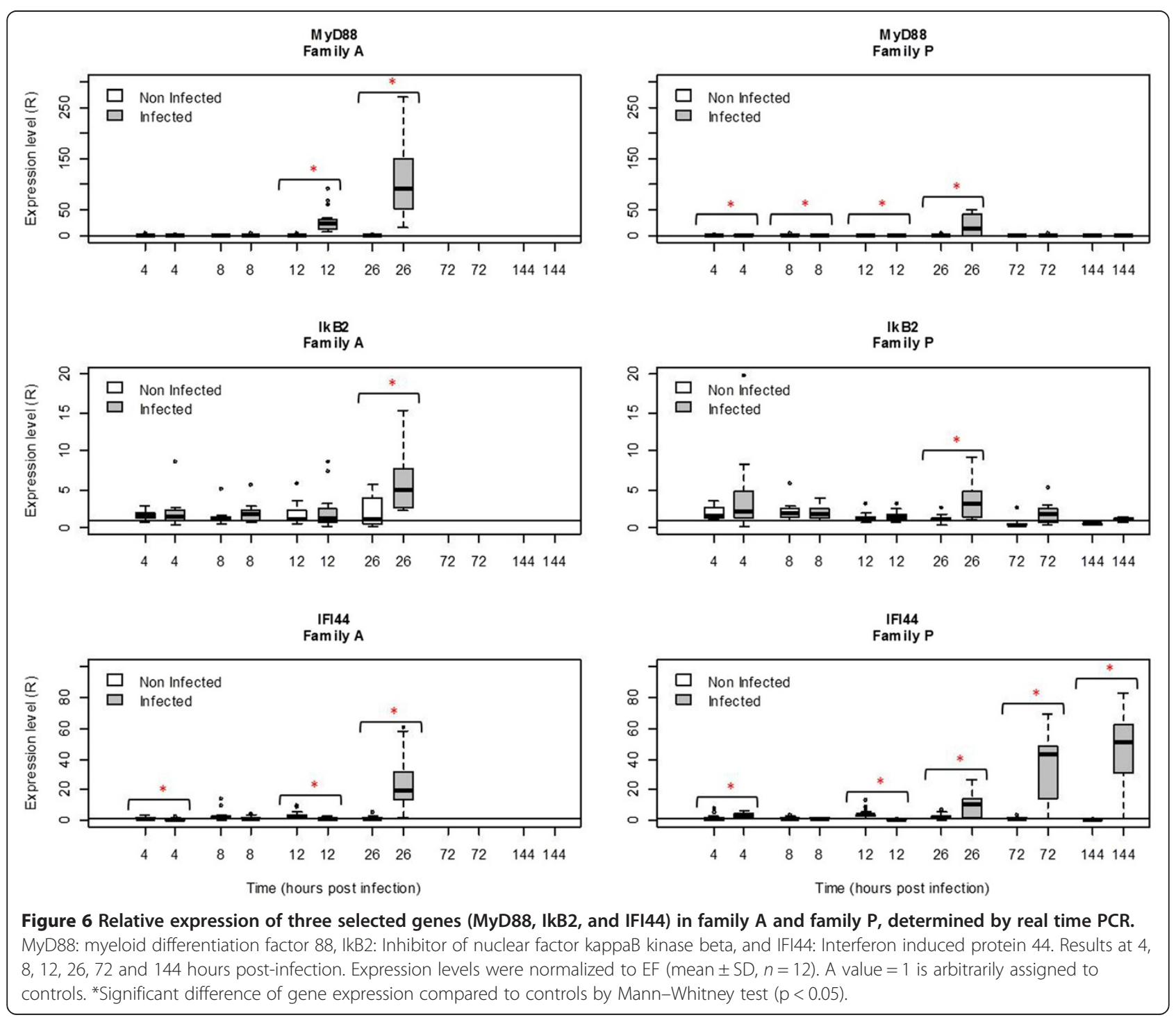




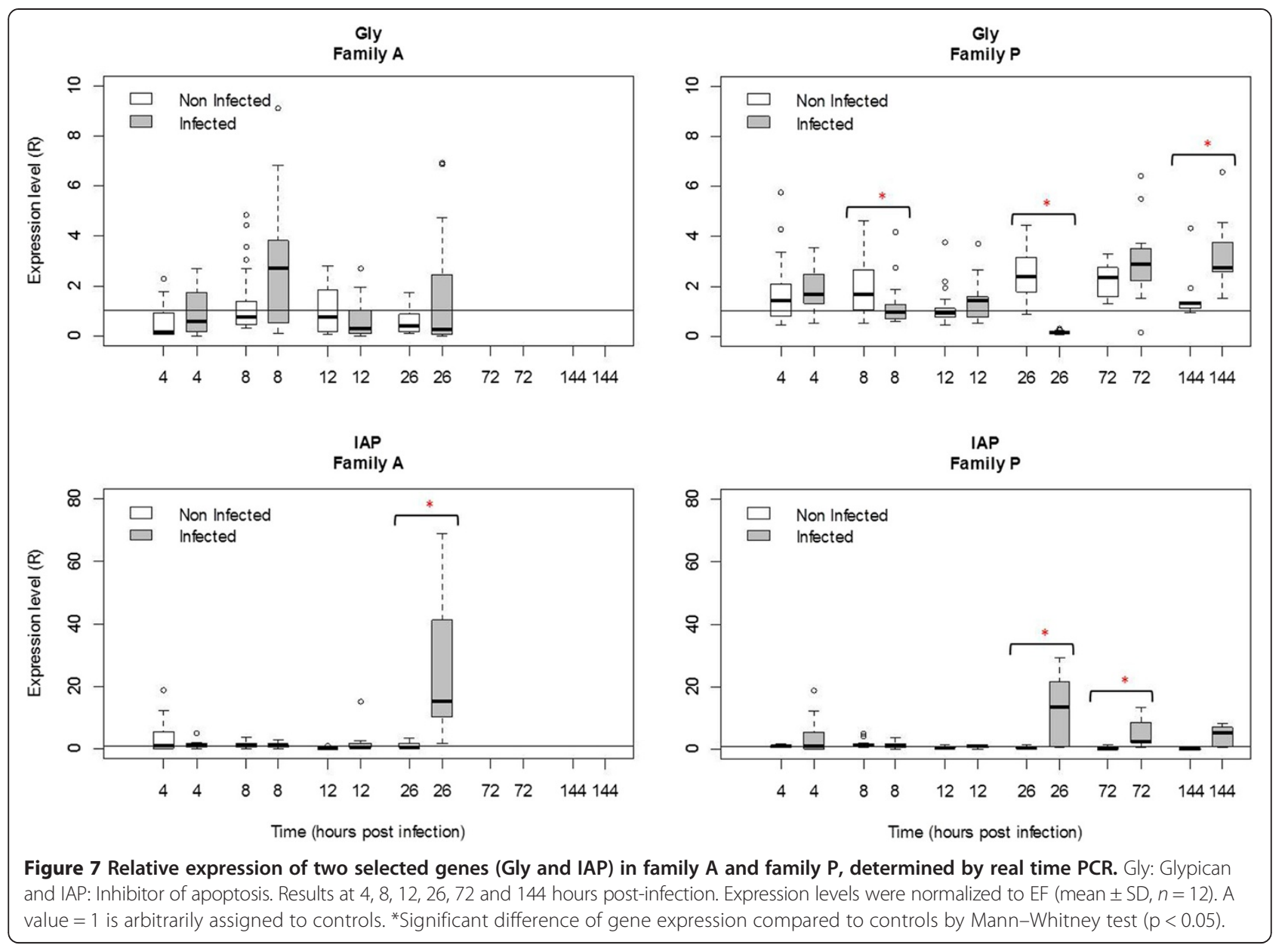

MyD88 increased significantly $(\mathrm{p}<0.05)$ at $12 \mathrm{hpi}$ and 26 hpi in infected oysters $(R=28.4$ and $R=122.2$, respectively) comparatively to its level of expression in negative control oysters $(R=1.2$ at 12 hpi and $R=0.9$ at 26 hpi) (Figure 6). In family P, MyD88 transcript levels decreased at 12 hpi $(R=0.2)$ and subsequently increased at 26 hpi ( $R=20.4$ fold) as compared with their level in negative control oysters $(\mathrm{p}<0.05)$. However, MyD88 transcript levels were similar in infected and negative control oysters at 72 and 144 hpi. For the IAP oyster gene, transcript levels increased significantly $(\mathrm{p}<0.05)$ at $26 \mathrm{hpi}$ in infected oysters $(R=25.5)$ versus controls $(R=2.1)$ of family A. In family $\mathrm{P}$, this level was also up-regulated at 26 and 72 hpi in infected oysters $(R=11.9$ and $R=5.2$, respectively) versus control oysters $(R=1.5$ and $R=1.2$ respectively) ( $\mathrm{p}<0.05)$ (Figure 7$)$. For IkB2 gene, the number of transcripts increased at $26 \mathrm{hpi}$ in infected oysters in both A and P families $(\mathrm{R}=6.4$ and $\mathrm{R}=3.7$ respectively, $\mathrm{p}<0.05$ ) (Figure 6).

For the Gly gene, no significant change was observed between infected and control oysters in family A. In family P, the Gly transcript level (Figure 7) was down-regulated at 8 hpi and 26 hpi $(R=1.7$ and $R=0.1$ respectively) in infected oysters compared to controls $(\mathrm{R}=1.2$ and $\mathrm{R}=$ 2.5 respectively). Then Gly transcript levels were upregulated at 144 hpi in infected oysters versus controls $(\mathrm{R}=3.2$ versus $\mathrm{R}=1.3, \mathrm{p}<0.05)$.

Throughout the experiment, the relative expression of these genes did not follow a consistent pattern as they were alternatively up-regulated or down-regulated. This is particularly noticeable in the case of MyD88, IFI44 and Gly.

Using Spearman's test, a rank correlation was determined between the expression of oyster genes and viral DNA amounts. Expression levels of MyD88 (Rs $=0.7$ ), IkB2 (Rs $=0.43)$, IFI44 $(\mathrm{Rs}=0.59)$ and IAP $(\mathrm{Rs}=0.47)$ were positively correlated with viral DNA amount in family A. In family P, a positive correlation was observed only for IFI44 $(\mathrm{Rs}=0.46)$ and IAP $(\mathrm{Rs}=0.48)($ Table 2$)$.

In order to compare oyster gene expression levels between families $A$ and $P$, an $R f$ ratio was calculated $(R f=R$ of family $A / R$ of family $P$ ). Our results show differences concerning the expression level of each gene during experimental challenge in controls in families $\mathrm{A}$ and $\mathrm{P}$. Nevertheless, at 4 hpi down-regulation of five genes was reported in infected oysters from family A in comparison 
Table 2 Viral load and correlation with the levels of expression of four selected in family $A$ and family $P$ (Rs Spearman correlation)

\begin{tabular}{lccrcc}
\hline \multirow{2}{*}{ Oyster genes } & \multicolumn{2}{c}{ Family $\mathbf{~}$} & & \multicolumn{2}{c}{ Family $\mathbf{P}$} \\
\cline { 2 - 3 } \cline { 5 - 6 } & Rs & $\boldsymbol{p}$ value & & Rs & $\boldsymbol{p}$ value \\
\hline MyD88 & 0.70 & $<0.0001$ & & 0.23 & 0.09 \\
IkB2 & 0.43 & $<0.0001$ & & 0.10 & 0.46 \\
IFI44 & 0.59 & $<0.0001$ & & 0.46 & $<0.0001$ \\
Gly & -0.18 & 0.26 & & -0.03 & 0.83 \\
IAP & 0.47 & $<0.0001$ & & 0.48 & $<0.0001$ \\
\hline
\end{tabular}

with family P. At $8 \mathrm{hpi}$, expression levels were similar in both families. At 12 hpi MyD88 were strongly upregulated and Gly was down-regulated in infected animals belonging to family A compared to family P. Finally at 26 hpi, MyD88 and Gly were up-regulated in family A as compared with family P (Table 3 ).

\section{Discussion}

The objective of the present study was to compare the susceptibility of Pacific oyster families towards experimental infection by OsHV-1 and to further analyze the basis for contrasted susceptibility in two particular families. In this study, the injection protocol was selected in order to obtain a synchronous infection in all animals at the same time. In our experiments, survival at 120 hours post injection (hpi) was highly variable among the 16 tested families and remained diverse at $144 \mathrm{hpi}$ between families A and P. This result suggests great variability of susceptibility to the viral infection in experimental conditions [22]. Sauvage et al. [10] previously suggested that a significant genetic component exists for susceptibility to the viral infection.

OsHV-1 DNA amounts increased sharply until $26 \mathrm{hpi}$ in family A and to a lesser extent in family P until 72 hpi. The amount of detected OsHV-1 DNA decreased at 144 hpi in family P. The peak of viral DNA copy number preceded the peak of mortality for both families. These results suggest that the virus replicated better in family A, which was affected by the highest mortality rates. In family $\mathrm{P}$, mortality rates remained low but OsHV-1 was

Table 3 Transcript ratios for each studied gene in families $A$ and $P(R f=R$ family $A / R$ family $P$ ) at different time points prior to the onset of mortality

\begin{tabular}{|c|c|c|c|c|c|c|c|c|}
\hline \multirow[t]{2}{*}{ Genes } & \multicolumn{4}{|c|}{ Control } & \multicolumn{4}{|c|}{ Infected } \\
\hline & $4 \mathrm{~h}$ & $8 \mathrm{~h}$ & $12 \mathrm{~h}$ & $26 \mathrm{~h}$ & $4 \mathrm{~h}$ & $8 \mathrm{~h}$ & $12 \mathrm{~h}$ & $26 \mathrm{~h}$ \\
\hline MyD88 & 2.2 & 0.6 & 3.6 & 1.0 & 0.7 & 2.0 & 158.3 & 6.0 \\
\hline |kB2 & 0.9 & 0.7 & 1.3 & 1.8 & 0.7 & 1.0 & 1.5 & 1.7 \\
\hline$|F| 44$ & 1.0 & 1.5 & 0.8 & 0.8 & 0.2 & 1.0 & 3.7 & 2.4 \\
\hline Gly & 0.3 & 0.6 & 1.0 & 0.2 & 0.5 & 2.4 & 0.5 & 10.0 \\
\hline IAp & 3.7 & 0.8 & 0.3 & 1.8 & 0.3 & 0.9 & 2.7 & 2.1 \\
\hline
\end{tabular}

able to replicate. Notwithstanding the development of an active infection some individuals belonging to this family appeared to recover from the infection. Conversely, Verrier et al. [23] showed that resistant cell lines obtained from rhabdovirus-infected fish clones did not support virus production whereas strong virus production took place in a highly susceptible cell line. On the contrary, Purcell et al. [24] reported results that are consistent with those observed in the present study, as resistant rainbow trout families showed lower Infectious hematopoietic necrosis virus (IHNV) replication, particularly at very early stages of infection. Others authors investigated the genetic basis underlying contrasted susceptibility to Marek's disease virus (MDV) in chicken through experimental trials $[25,26]$.

Heatmap approach was selected to compare the global viral gene expression profiles for the 39 selected OsHV1 genes in infected Pacific oysters from families A and P.

Although mortality rates remained very low for family $\mathrm{P}$, virus gene transcripts were detected. Expression levels were clearly different between family A and family P. Cluster studies showed that viral ORFs were overexpressed in family A as compared with family P during the course of time. However, most of the analyzed viral genes $(82 \%)$ had a similar expression profile in both families. Three different expression profiles were observed in both families: low, moderate and high expression. Among the latter, viral IAP genes (ORF 42, ORF 87 and ORF 99) were identified, suggesting that OsHV1 may actively manipulate host apoptosis in order to multiply itself. Interestingly, in oysters from the family demonstrating the highest susceptibility to the viral infection (family A) all 39 ORFs were up expressed at 26 hpi in comparison to the less susceptible one (family P). As for virus DNA detection, expression of gene transcripts confirmed that OsHV-1 was able to replicate in oysters from family $\mathrm{P}$ to a lesser extent than in oysters from family A. Although virus infection effectively developed in Pacific oysters from family P, most animals appeared to recover from the infection. Moreover, a decrease in the amount of virus transcripts until they became undetectable at 144 hpi was recorded in family P. This result suggests that the virus may enter a persistence/latency phase as described in vertebrate herpesviruses. However, $70 \%$ of OsHV-1 genes encode putative proteins with unknown function, which makes the study of virus interactions and of the viral cycle particularly difficult. Other studies would be necessary to further unravel the development of the cycle of OsHV-1, including functional genomics analysis.

Our data also shows high variability of virus gene expression in both oyster families. This could be explained by the involvement of more than one OsHV-1 genotype in the infectious process. However, partial sequencing 
and genotyping of six viral microsatellite loci indicated the presence of a unique OsHV-1 genotype ( $\mu$ Var), in both families after the onset of viral infection (data not shown). The observed variability may therefore be interpreted as the presence in each oyster family of individuals with different degrees of susceptibility to the same OsHV-1 genotype.

These results confirm a genetic basis for susceptibility to OsHV-1 infection in the Pacific oyster $[10,11]$. Moreover, they suggest that oysters belonging to family $\mathrm{P}$, the less susceptible one, could be able to circumvent infection by OsHV-1 after experimental inoculation of the virus challenge. In this family, a phase of active virus replication took place, as demonstrated by the initial increase of viral DNA and RNA. Ensuing this phase, virus DNA and RNA amounts decreased rapidly suggesting that the host immune defense had been activated and that it might be effective to limit virus multiplication $[27,28]$. To explore this hypothesis, the expression of immune related genes [20,29] was also monitored by real time PCR.

The expression levels of five host genes (Myeloid differentiation 88 (MyD88), Interferon induced protein 44 (IFI44), Glypican (Gly), Inhibitor of nuclear factor kap$\mathrm{paB}$ kinase beta (IkB2), Inhibitor of Apoptosis (IAP)) were thus analyzed in families A and P. In our study, transcript ratios shown small differences ( $\mathrm{Rf}>1$ ) in control oysters suggesting a family effect on the gene expression. Nevertheless, this ratio was highly different in infected oysters, especially at 12 and 26 hpi for MyD88. It was previously shown that the expression of three of these genes (MyD88, IFI44 and Gly) in C. gigas haemocytes is modulated after a contact with OsHV-1 [20]. In the case of IkB2, decreased abundance of its transcripts was associated with a certain level of resistance to summer mortality [13]. Finally, an inhibitor of apoptosis (IAP) was selected for this study due to the fact that it could play a pivotal role in the Pacific oyster immune defense [30].

MyD88 transcripts were up-regulated at $26 \mathrm{hpi}$ in infected Pacific oysters from both families, although upregulation was higher in family $A(R f=6)$. In this family, the expression level of MyD88 was positively correlated with viral DNA amounts in family A (Rs $=0.70, \mathrm{p}<$ $0.00001)$ whereas no significant correlation was detected in family P ( $p>0.05)$. MyD88 is a universal adapter for the TLR/IL-1R family (TIR). It has been described in many species including humans [31], fish [32], drosophila [33], and molluscs [34]. Several studies demonstrated that MyD88-deficient mice were susceptible to HSV-1 infection $[35,36]$. The signaling pathway via MyD88 is initiated to activate nuclear factor-kappa B (NF-kB), cJun NH2 terminal kinase (Jnk) and mitogen-activated proteins kinase (MAPKs) [37]. IkB2 transcripts showed significant up-regulation only at $26 \mathrm{hpi}$ in both families and expression levels were almost identical in both families $(\mathrm{Rf}=1.7)$. Nevertheless, the positive correlation of the expression level of IkB2 and viral DNA amounts was only observed in family $A(R s=0.43, p<0.0001)$. IkB2 is a member of NF-kappaB signal pathway and plays an important role in regulating the innate immune response of invertebrates. Zhang et al. [38] described IkB2 mRNA up-regulation in hemocytes at different time-points (2 and $24 \mathrm{hpi}$ ) after contact with Vibrio alginolyticus in pearl oyster. Over-expression of both MyD88 and IKB2 genes suggests a crucial role of the NF-kappaB signal pathway in virus recognition and cell activation [39]. Some viruses, such as the African swine fever virus (ASFV) [40], HIV [41,42] or EBV [43] have evolved strategies to interfere with NF-kB activation in order to evade the immune response. However, viruses can also activate NF-kB to block apoptosis and prolong survival of the host cell in order to gain time for replication and increase the production of viral progeny [44].

Although MyD88 is reported as a key element in the activation of immunity, over-expression of this gene appeared higher in Pacific oysters belonging to family A, which is more susceptible to OsHV-1 infection. In this context, the over expression of MyD88 could be interpreted more as a marker of infectious processes and viral replication than that of an effective antiviral response. Gagnaire et al. [45] previously suggested that gene over-expression in Pacific oysters could lead to tissue injury and thus result in higher mortality rates. Defense mechanisms may play a key role in pathogenesis as they induce cell and tissue damages [46,47].

Here, IFI44 was highly up-regulated in both families and continued to increase in family $\mathrm{P}$ at $72 \mathrm{hpi}$. The detection of increasing levels of IFI44 transcripts in oysters from this family between $72 \mathrm{hpi}$ and 144 hpi was thus concomitant with the detection of decreasing amounts of OsHV-1 DNA and RNA by real-time PCR. Nevertheless, the analysis of data collected throughout the entire experiment reveals an overall positive correlation between the expression of this gene and viral DNA amounts in both families ( $\mathrm{Rs}=0.46, \mathrm{p}<0.0001$ ). This result suggests that IFI44 may be a key element for effective antiviral defense against infection by OsHV-1 infection as it provides Pacific oysters with the ability to circumvent the virus proliferation. IFI44 gene is a member of the IFNs $(\mathrm{IFN} \alpha / \beta)$ inducible gene family and may function as a mediator of antiviral activity against hepatitis $\mathrm{C}$ or $\mathrm{D}$ virus infections through interferons $[48,49]$. However, the role of IFI44 in antiviral immune response remains unclear.

The glypican transcript level decreased significantly 8 hpi in family $\mathrm{P}$ whereas no change was observed in family A as shown by the Rf value. Glypicans belong to a family of heparan sulfate proteoglycans that are linked 
to the cell surface by a glycosylphosphatidylinositol (GPI) anchor [49]. Heparan sulfate proteoglycans may be used by different viruses including herpesviruses as cellular receptors [50]. Binding of a viral protein to heparan sulfate is the first step in a cascade of interactions between viruses and cells that is required for viral entry into the cells and the initiation of infection. $\mathrm{CHO}$ cells treated with heparinases that prevent heparan sulfate biosynthesis have reduced capacity to bind HSV-1 and are at least partially resistant to HSV-1 infection [51]. Therefore, our results suggests that reduced glypican levels in family P may obstruct or hinder to some extent OsHV-1 entry in host cells and contribute to this family decreased susceptibility to viral infection.

IAP cellular transcripts were respectively up-regulated in families A and P between 12 hpi and 26 hpi and between $26 \mathrm{hpi}$ and $72 \mathrm{hpi}$. Our study showed a positive correlation between the level of IAP transcripts and the amounts of viral DNA in both families $(\mathrm{Rs}=0.47, \mathrm{p}<$ 0.0001 for family A and Rs $=0.48, \mathrm{p}<0.0001$ for family P). IAP proteins are conserved throughout animal evolution and can block apoptosis. Apoptosis is one of the major mechanisms of anti-viral response [52]. Overexpression of IAP could be a reaction to the apoptotic process induced by OsHV-1 infection. Nevertheless, some pathogens enter a cell and inhibit apoptosis to increase their life span [53]. All the members of the gamma-herpesvirus family encode genes that are able to inhibit apoptosis including, one or two $\mathrm{Bcl}-2$ homologues [54]. Moreover, studies have shown that HSV-1 require gene Us5 to protect itself from apoptosis induced by certain stimuli [55]. Finally, the contribution of apoptosis to the pathogenesis of West Nile Virus (WNV) encephalitis has been demonstrated by several studies [56,57].

\section{Conclusion}

This work is the first step towards elucidating the interactions between OsHV-1 and its host, the Pacific oyster (C. gigas). It also represents the first study of viral gene expression in oyster families with contrasted susceptibility to virus infection. In two particular families, contrasted susceptibility was associated with significantly different amounts of virus DNA and RNA, which suggests that susceptibility of Pacific oysters to OsHV-1 may be affected by genetic variations. Previous studies support the hypothesis of a genetic basis underlying resistance to OsHV-1 infection in the Pacific oyster. In addition, the observed differences in terms of susceptibility to infection by OsHV-1 were associated with differences in host gene expression profiles. Finally, the present study is also the first to show positive correlations between viral DNA amounts and the expression of selected oyster genes. These results suggest that the upregulation of immune related genes may prevent virus replication and open new questions regarding the persistence and/or latency of the virus within the host. Genes of interest could be further evaluated in oyster breeding programs to determine if they confer genetic resistance to OsHV-1. Such an integrative strategy could be applied to other infectious diseases.

\section{Methods}

\section{Animals}

Wild oysters Crassostrea gigas were randomly sampled from an oyster reef in the Marennes-Oléron Bay in January 2011. The broodstock was acclimated gradually to $21^{\circ} \mathrm{C}$ over an 8-day period, in one $120 \mathrm{~L}$ tank, with a flow of $400 \mathrm{~L} / \mathrm{h}$ during two months. In order to favor the gametogenesis, a cultured phytoplankton diet was added to the seawater with a continuous flow of $5 \mathrm{~L} / \mathrm{h}$ ( 1 million cells/ $\mathrm{mL}$ ) during this period (10\% Isochrysis galbana, 10\% Chaetoceros pumilum, 10\% Tetraselmis suecica, 10\% Pavlova lutheri and 70\% Skeletonema costatum). Sixteen biparental families, respectively named A to P were produced in the present study in March 2011 at the Ifremer hatchery in La Tremblade (Charente Maritime, France) during the course of the Bivalife EU funded project (FP7, 2011-2014). For each parent, spermatozoids or oocytes were individually collected by stripping the gonad of males and females respectively, and each crossing was performed following a previously reported protocol [58], and reared as described in Ernande et al. [22].

No specific permits are required at national and European levels for the described experimental study. The Pacific oyster C. gigas is not an endangered or a protected species.

\section{Defining OsHV-1 susceptibility of 16 Pacific oyster families}

Experimental infections were carried out using the 16 produced families ( 9 months old, $3 \mathrm{~cm}$ ). Thirty spat of each family were "anaesthetized" during $4 \mathrm{~h}$ in a solution containing magnesium chloride $\left(\mathrm{MgCl}_{2}, 50 \mathrm{~g} / \mathrm{L}\right)$ in a mixture of seawater $(1 \mathrm{v}) /$ distilled water (4 v) [59]. One hundred $\mu \mathrm{L}$ of an OsHV-1 ( $\mu$ Var, [21]) suspension adjusted at $10^{3}$ copies of viral $\mathrm{DNA} / \mu \mathrm{L}$ were injected into the adductor muscle of each individual using a $1 \mathrm{~mL}$ syringe [59]. Pacific oysters were then placed in 3 tanks (10 oysters per tank) containing $5 \mathrm{~L}$ of filtered seawater $(1 \mu \mathrm{m})$ at $22^{\circ} \mathrm{C}$. Similarly, 30 spat from each family were injected with $100 \mu \mathrm{L}$ of artificial seawater as a control. Mortality was checked every day. Two similar assays were conducted in October 2011.

\section{Experimental infection of two oyster families presenting contrasted OsHV-1 susceptibility}

A third trial was carried out. One hundred and sixty oysters $(10$ month old, $3 \mathrm{~cm}$ ) from families A and P were "anesthetized" during $4 \mathrm{~h}$ as previously described. One 
hundred $\mu \mathrm{L}$ of artificial seawater or a viral suspension at $10^{3}$ copies of viral $\mathrm{DNA} / \mu \mathrm{L}$ ( $\mu \mathrm{Var}$ ) were injected into the adductor muscle of 80 oysters for each family as already reported [59]. Oysters were then distributed in 4 tanks per condition (seawater vs viral suspension) and per family (20 animals per tank). One tank per condition was dedicated to record survival and the three others were dedicated for the sampling.

Four live oysters per tank, condition and family were collected $0,4,8,12$ and 26 hours post-injection (hpi) for both families, as well as 72 hpi and 144 hpi for family P. Two pieces of mantle were sampled from each individual. The first piece (50 to $100 \mathrm{mg}$ ) was disposed in a tube containing $1 \mathrm{~mL}$ of TRIZOL $^{\circ}$ Reagent $^{\mathrm{mu}}$ (Ambion $^{\circ}$ ) and frozen at $-80^{\circ} \mathrm{C}$ for RNA extraction. The second piece was directly frozen at $-20^{\circ} \mathrm{C}$ in a tube for DNA extraction.

\section{Total DNA or RNA extraction and CDNA synthesis}

DNA extraction was performed with QiAamp tissue mini kit $^{\circ}$ (QIAgen) according to the manufacturer's protocol. Elution was performed in $100 \mu \mathrm{L}$ of $\mathrm{AE}$ buffer provided in the kit.

Total RNA was extracted using TRIZOL ${ }^{\bullet}$ Reagent $^{\mathrm{m}}$ (Ambion ${ }^{\circ}$ ) according to the manufacturer's recommendations. Total RNA was treated with Turbo ${ }^{\mathrm{Tx}}$ DNAse $\left(\right.$ Ambion $\left.^{\circ}\right)$ to remove genomic DNA. The RNA quality and quantity were determined using NanoDrop 2000 (Thermo Scientific) and Bioanalyser 2100 (Agilent). Firststrand cDNA synthesis was carried out using the SuperScript $^{\circ}$ III First-Strand Synthesis System (Invitrogen) using $8000 \mathrm{ng}$ of RNA treated. A No RT was performed after each DNAse treatment using real time PCR in order to control absence of oyster and/or virus genomic DNA using EF primers (Table 4) and C9/C10 primers [60] respectively.

\section{OsHV-1 DNA quantification and gene expression by real-time PCR}

\section{OsHV-1 DNA quantification}

OsHV-1 DNA quantification was carried out in the third trial using a real-time PCR protocol [61]. Real-time PCR was performed in duplicate using a Mx3000 Thermocycler sequence detector (Agilent). Amplification reactions were performed in a total volume of $20 \mu \mathrm{L}$. Each well contained $5 \mu \mathrm{L}$ of genomic DNA $(5 \mathrm{ng} / \mu \mathrm{L}), 10 \mu \mathrm{L}$ of Brillant III Ultra-Fast $\mathrm{SYBR}^{\circ}$ Green Master Mix (Agilent), $2 \mu \mathrm{L}$ of each primer $(3 \mu \mathrm{M})$ and $1 \mu \mathrm{L}$ of distilled water. Real time PCR cycling conditions were as follow: $3 \mathrm{~min}$ at $95^{\circ} \mathrm{C}$, followed by 40 cycles of amplification at $95^{\circ} \mathrm{C}$ for $5 \mathrm{~s}, 60^{\circ} \mathrm{C}$ for $20 \mathrm{~s}$. Melting curves were also plotted $\left(55-95^{\circ} \mathrm{C}\right)$ in order to ensure that a single PCR product was amplified for each set of primers. Negative controls (without DNA) were included.

\section{Viral gene expression}

Real-time quantitative RT PCR was used to study the expression of 39 viral genes using the previously described protocol with $5 \mu \mathrm{L}$ of cDNA dilution (1/30) instead of genomic DNA [18]. Normalized relative viral gene expression levels were calculated for each individual with formula: $\mathrm{F}=\log _{10}\left[(\mathrm{E}+1)^{40-\mathrm{Ct}} / \mathrm{N}\right]$ adapted from De Decker et al. [62], where $\mathrm{E}$ is efficiency of each ORFs [18], Ct (threshold cycle) corresponds to the PCR cycle number, N is the maximal number $\left(10^{7}\right)$ of viral DNA copies/ng of total DNA detected minus number of viral DNA copies/ ng of total DNA determinate by absolute real time PCR for each individual and $\mathrm{Ct}=40$ is arbitrarily considered to

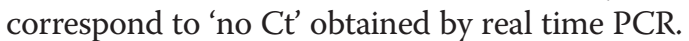

Table 4 List of oyster genes targeted by real time PCR

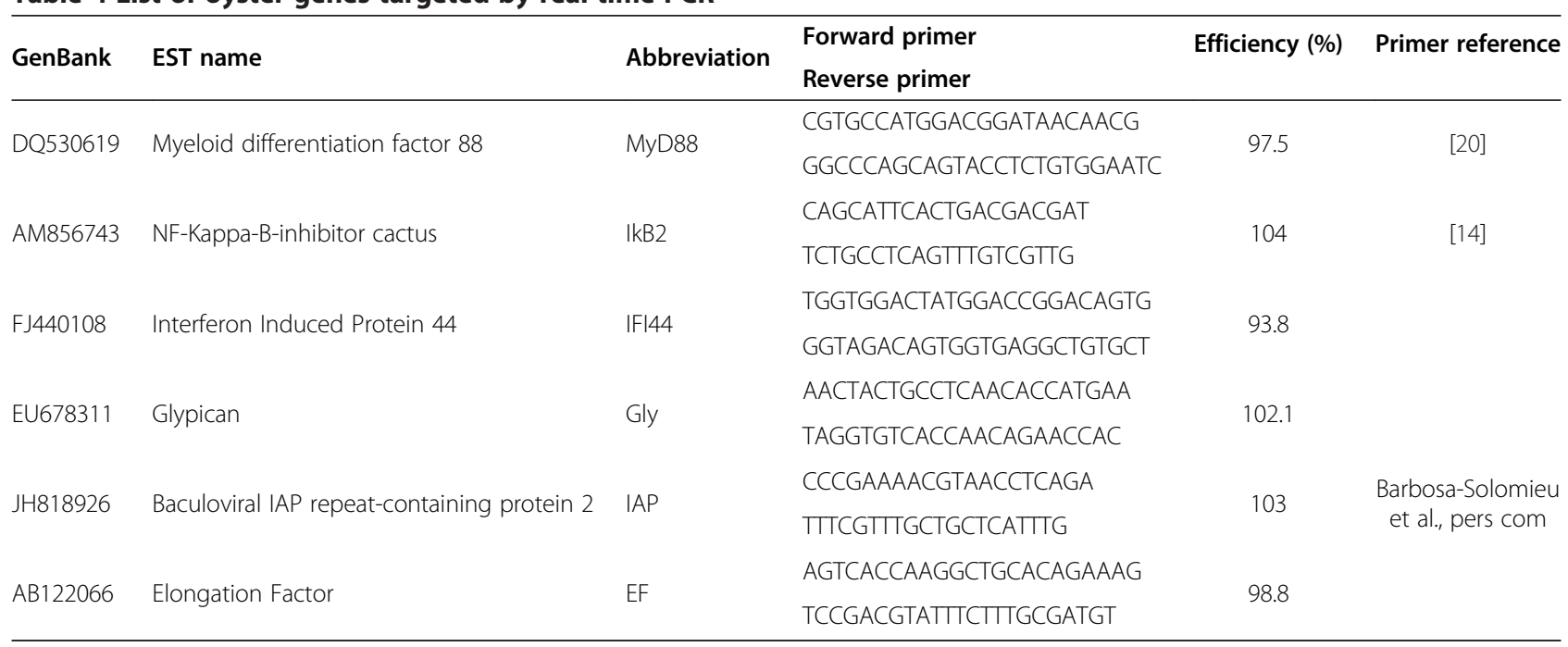




\section{Host gene expression}

Moreover, the relative expression of five genes from Crassostrea gigas spat were studied during the third OsHV-1 experimental infection at 4, 8, 12, 26 hpi for both families and 72 and 144 hpi for family P. The relative quantification value (ratio $\mathrm{R}$ ) was calculated using the method described by Pfaffl [63]: $\mathrm{R}=\left[\left(\mathrm{E}_{\text {target }}\right)^{\Delta \mathrm{CT} \text { target(control-sample) }}\right] /$ $\left[\left(\mathrm{E}_{\mathrm{EF} \alpha-1}\right)^{\Delta \mathrm{CT} E F \alpha-1 \text { (control-sample) }}\right]$. The efficiency of each primer pair was determined by constructing a standard curve from serial dilutions (Table 4). These 5 genes from Pacific oyster were (i) myeloid differentiation factor 88 (MyD88), (ii) NF kappa-B inhibitor cactus (IkB2), (iii) interferoninduced protein 44 (IFI44), (iv) glypican (Gly), (v) Baculoviral apoptosis inhibitor repeat-containing protein 2 (IAP) genes (Table 4). Host gene expression was normalized to the elongation factor I (EF), as no significant differences of $\mathrm{Ct}$ values were observed for this housekeeping gene between several conditions during the course time $(\mathrm{CV}=3.2 \%$, Kruskal-Wallis test $\mathrm{Z}=0.19$, $\mathrm{p}>$ 0.05). Nevertheless, the variance analysis of EF Ct value demonstrated a significant difference were between families (Kruskal-Wallis test, $\mathrm{Z}=2.19, \mathrm{p}<0.05$ ). The calibrator used for the experiment consisted of individuals sampled at time 0 hpi from each family.

\section{Data analysis}

Kaplan-Meier survival curves and the Wilcoxon test were used to characterize and compare survival between oyster families.

Cts were calculated with the Stratagene Mxpro software 4.0. A heatmap was generated in order to represent the viral gene expression using the 'pheatmap' package in $\mathrm{R}$. Clustering of viral genes was performed using the euclidean method. Results for relative expression of oyster genes were expressed as boxplot. Kruskal-Wallis and Dunn's tests were used to analyze viral clusters, and a MannWhitney test was used to analyze oyster gene expression.

Correlations between viral load and oyster gene expression were tested with the Spearman's nonparametric rho (Rs). All statistical computations were performed with the XLSTAT software (version 2013), and results were declared statistically significant at the two-sided $5 \%$ (i.e., $\mathrm{P}<0.05)$. The $\mathrm{Rf}$ ratio was calculated using the expression level $(R)$ in family $A$ / the expression level $(R)$ in family $\mathrm{P}$ in order to compare the oyster gene expression between both families.

\section{Competing interests}

This work was supported by Ifremer (Institut Français pour l'Exploitation de la Mer). The authors declare that they have no competing interests.

\section{Authors' contributions}

This study is the result of a collective work. AS, MAT and TR conceived this study, and participated in its design. All others carried out experimental trials. AS and TR drafted the manuscript. All authors read, corrected, and approved the final manuscript.

\section{Acknowledgement}

The authors wish to thank the Ifremer hatchery team (LGPMM) in La Tremblade and the nursery team (LSPC) in Bouin for the production of Pacific oysters. This work was supported by the EU funded project Bivalife (PF7, $n^{\circ}$ 266157), the project MOLTRAQ (ERA NET EMIDA) and the Region Poitou-Charentes. Thanks to G. Tchaleu for virus genotyping and B. Morga for his comments and suggestions on the manuscript.

\section{Author details}

${ }^{1}$ Ifremer (Institut Français de Recherche pour l'Exploitation de la Mer), Unité Santé Génétique et Microbiologie des Mollusques (SG2M), Laboratoire de Génétique et Pathologie des Mollusques Marins (LGPMM), Avenue de Mus de Loup, 17390 La Tremblade, France. ${ }^{2}$ Ifremer, Laboratoire Environnement Ressources des Pertuis Charentais (LERPC), Avenue de Mus de Loup, 17390 La Tremblade, France.

Received: 4 March 2014 Accepted: 1 July 2014

Published: 9 July 2014

\section{References}

1. Davison AJ, Trus BL, Cheng N, Steven AC, Watson MS, Cunningham C, Le Deuff R-M, Renault T: A novel class of herpesvirus with bivalve hosts. J Gen Virol 2005, 86(Pt 1):41-53.

2. Davison AJ, Eberle R, Ehlers B, Hayward GS, McGeoch DJ, Minson AC, Pellett PE, Roizman B, Studdert MJ, Thiry E: The order Herpesvirales. Arch Virol 2009, 154:171-177.

3. Renault T, Moreau P, Faury N, Pepin J-F, Segarra A, Webb S: Analysis of clinical Ostreid herpesvirus 1 (Malacoherpesviridae) specimens by sequencing amplified fragments from three virus genome areas. J Virol 2012, 86:5942-5947.

4. Jenkins C, Hick P, Gabor M, Spiers Z, Fell SA, Gu X, Read A, Go J, Dove M, $\mathrm{O}^{\prime}$ Connor W, Kirkland PD, Frances J: Identification and characterisation of an ostreid herpesvirus-1 microvariant (OsHV-1 $\mu$-var) in Crassostrea gigas (Pacific oysters) in Australia. Dis Aquat Organ 2013, 105:109-126.

5. Renault T: Pacific Cupped Oyster, Crassostrea gigas, Mortality Outbreaks and Infectious Diseases. In Oysters Physiol Ecol Distrib Mortal. Edited by Qin JG. New York: Nova Science Publishers Inc; 2012:203-225 [Chapter 8].

6. Dégremont L, Bédier E, Boudry P: Summer mortality of hatchery-produced Pacific oyster spat (Crassostrea gigas). II. Response to selection for survival and its influence on growth and yield. Aquaculture 2010, 299:21-29.

7. Kiryluk K, Martino J, Gharavi AG: Genetic susceptibility, HIV infection, and the kidney. Clin J Am Soc Nephrol 2007, 2(Supplement 1):S25-S35.

8. Moraru M, Cisneros E, Gómez-Lozano N, de Pablo R, Portero F, Cañizares M, Vaquero M, Roustán G, Millán I, López-Botet M, Vilches C: Host genetic factors in susceptibility to herpes simplex type 1 virus infection: contribution of polymorphic genes at the interface of innate and adaptive immunity. J Immunol 2012, 188:4412-4420.

9. Schmitt P, Santini A, Vergnes A, Degremont L, de Lorgeril J: Sequence polymorphism and expression variability of Crassostrea gigas immune related genes discriminate two oyster lines contrasted in term of resistance to summer mortalities. PLoS One 2013, 8:e75900.

10. Sauvage $C$, Pépin JF, Lapègue $S$, Boudry $P$, Renault $T$ : Ostreid herpes virus 1 infection in families of the Pacific oyster, Crassostrea gigas, during a summer mortality outbreak: Differences in viral DNA detection and quantification using real-time PCR. Virus Res 2009, 142:181-187.

11. Sauvage C, Boudry P, de Koning D-J, Haley CS, Heurtebise S, Lapègue S: QTL for resistance to summer mortality and OsHV-1 load in the Pacific oyster (Crassostrea gigas). Anim Genet 2010, 41:390-399.

12. Jouaux A, Lafont M, Blin J-L, Houssin M, Mathieu M, Lelong C: Physiological change under OsHV-1 contamination in Pacific oyster Crassostrea gigas through massive mortality events on fields. BMC Genomics 2013, 14:590.

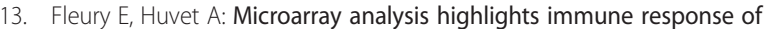
Pacific oysters as a determinant of resistance to summer mortality. Mar Biotechnol 2012, 14:203-217.

14. Normand J, Li R, Quillien V, Nicolas J-L, Boudry P, Pernet F, Huvet A: Contrasted survival under field or controlled conditions displays associations between mRNA levels of candidate genes and response to OsHV-1 infection in the Pacific oyster Crassostrea gigas. Mar Genomics 2014, 12:95-102. 
15. Zhang G, Fang X, Guo X, Li L, Luo R, Xu F, Yang P, Zhang L, Wang X, Qi H, Xiong Z, Que H, Xie Y, Holland PWH, Paps J, Zhu Y, Wu F, Chen Y, Wang J, Peng C, Meng J, Yang L, Liu J, Wen B, Zhang N, Huang Z, Zhu Q, Feng Y, Mount A, Hedgecock D, et al: The oyster genome reveals stress adaptation and complexity of shell formation. Nature 2012, 490:49-54.

16. Fleury E, Moal J, Boulo V, Daniel J-Y, Mazurais D, Hénaut A, Corporeau C, Boudry $P$, Favrel $P$, Huvet A: Microarray-based identification of gonad transcripts differentially expressed between lines of Pacific oyster selected to be resistant or susceptible to summer mortality. Mar Biotechnol 2009, 12:326-339.

17. Dheilly NM, Lelong C, Huvet A, Favrel P: Development of a Pacific oyster (Crassostrea gigas) 31,918-feature microarray: identification of reference genes and tissue-enriched expression patterns. BMC Genomics 2011, 12:468.

18. Segarra A, Faury N, Pépin J-F, Renault T: Transcriptomic study of 39 ostreid herpesvirus 1 genes during an experimental infection. J Invertebr Pathol 2014, 119C:5-11.

19. Burge CA, Friedman CS: Quantifying Ostreid herpesvirus (OsHV-1) genome copies and expression during transmission. Microb Ecol 2012, 63:596-604

20. Renault T, Faury N, Barbosa-Solomieu V, Moreau K: Suppression substractive hybridisation (SSH) and real time PCR reveal differential gene expression in the Pacific cupped oyster, Crassostrea gigas, challenged with Ostreid herpesvirus 1. Dev Comp Immunol 2011, 35:725-735.

21. Segarra A, Pépin JF, Arzul I, Morga B, Faury N, Renault T: Detection and description of a particular Ostreid herpesvirus 1 genotype associated with massive mortality outbreaks of Pacific oysters, Crassostrea gigas, in France in 2008. Virus Res 2010, 153:92-99.

22. Ernande B, Clobert J, McCombie H, Boudry P: Genetic polymorphism and trade-offs in the early life-history strategy of the Pacific oyster, Crassostrea gigas (Thunberg, 1795): a quantitative genetic study. J Evol Biol 2003, 16:399-414.

23. Verrier ER, Langevin C, Tohry C, Houel A, Ducroca V, Benmansour A Quillet $E$, Boudinot P: Genetic resistance to Rhabdovirus infection in teleost fish is paralleled to the derived cell resistance status. PLoS One 2012, 7:e33935.

24. Purcell MK, Lapatra SE, Woodson JC, Kurath G, Winton JR: Early viral replication and induced or constitutive immunity in rainbow trout families with differential resistance to Infectious hematopoietic necrosis virus (IHNV). Fish Shellfish Immunol 2010, 28:98-105.

25. Wang Y, Qiu M, Yang J, Zhao X, Wang Y, Zhu Q, Liu Y: Sequence variations of the MHC class I gene exon 2 and exon 3 between infected and uninfected chickens challenged with Marek's disease virus. Infect Genet Evol 2014, 21:103-109.

26. Heifetz EM, Fulton JE, O'Sullivan NP, Arthur JA, Cheng H, Wang J, Soller M, Dekkers JC: Mapping QTL affecting resistance to Marek's disease in an F6 advanced intercross population of commercial layer chickens. BMC Genomics 2009, 10:20.

27. Klimpel GR: Immune Defenses. In Med Microbiol. 4th edition. Edited by Baron S. Galveston (TX): University of Texas Medical Branch at Galveston; 1996.

28. Levy JA: The importance of the innate immune system in controlling HIV infection and disease. Trends Immunol 2001, 22:312-316.

29. Green TJ, Montagnani C: Poly I:C against subsequent challenge with Ostreid herpesvirus (OsHV-1 $\mu$ var). Fish Shellfish Immunol 2013, 35:382-388.

30. Deveraux QL, Reed JC: IAP family proteins-suppressors of apoptosis. Genes Dev 1999, 13:239-252.

31. Hultmark D: Macrophage differentiation marker MyD88 is a member of the Toll/IL-1 receptor family. Biochem Biophys Res Commun 1994, 199:144-146.

32. Takano T, Kondo H, Hirono I, Saito-Taki T, Endo M, Aoki T: Identification and characterization of a myeloid differentiation factor 88 (MyD88) cDNA and gene in Japanese flounder, Paralichthys olivaceus. Dev Comp Immuno 2006, 30:807-816.

33. Horng T, Medzhitov R: Drosophila MyD88 is an adapter in the Toll signaling pathway. Proc Natl Acad Sci U S A 2001, 98:12654-12658.

34. Qiu L, Song L, Yu Y, Xu W, Ni D, Zhang Q: Identification and characterization of a myeloid differentiation factor 88 (MyD88) cDNA from Zhikong scallop Chlamys farreri. Fish Shellfish Immunol 2007, 23:614-623.

35. Mansur DS, Kroon EG, Nogueira ML, Arantes RME, Rodrigues SCO, Akira S, Gazzinelli RT, Campos MA: Lethal encephalitis in myeloid differentiation factor 88-deficient mice infected with herpes simplex virus 1. Am J Pathol 2005, 166:1419-1426.

36. Ma $Y$, He B: Recognition of herpes simplex viruses: toll-like receptors and beyond. J Mol Biol 2013, 426:1133-1147.

37. Janssens S, Beyaert R: A universal role for MyD88 in TLR/IL-1R-mediated signaling. Trends Biochem Sci 2002, 27:474-482.

38. Zhang D, Jiang S, Qiu L, Su T, Wu K, Li Y, Zhu C, Xu X: Molecular characterization and expression analysis of the IKB gene from pearl oyster Pinctada fucata. Fish Shellfish Immunol 2009, 26:84-90.

39. Santoro MG, Rossi A, Amici C: NF-kB and virus infection: who controls whom. EMBO J 2003, 22:2552-2560.

40. Revilla Y: Inhibition of nuclear factor kappa B activation by a virus-encoded Ikappa B-like protein. J Biol Chem 1998, 273:5405-5411.

41. Akari $\mathrm{H}$ : The human immunodeficiency virus type 1 accessory protein Vpu induces apoptosis by suppressing the nuclear factor kappaB-dependent expression of antiapoptotic factors. J Exp Med 2001, 194:1299-1312.

42. Bour S: The human immunodeficiency virus type $1 \mathrm{Vpu}$ protein inhibits NF-kappa B activation by interfering with beta TrCP-mediated degradation of Ikappa B. J Biol Chem 2001, 276:15920-15928.

43. Dreyfus DH, Nagasawa M, Pratt JC, Kelleher CA, Gelfand EW: Inactivation of NF-kappaB by EBV BZLF-1-encoded ZEBRA protein in human T cells. J Immunol 1999, 163:6261-6268.

44. Roulston A, Marcellus RC, Branton PE: Viruses and Apoptosis. Annu Rev Microbiol 1999, 53:577-628

45. Gagnaire B, Gay M, Huvet A, Daniel J-Y, Saulnier D, Renault T: Combination of a pesticide exposure and a bacterial challenge: In vivo effects on immune response of Pacific oyster, Crassostrea gigas (Thunberg). Aquat Toxicol 2007, 84:92-102.

46. Haslett C, Savill JS, Meagher L: The neutrophil. Curr Opin Immunol 1989, 2:10-18.

47. Sherwood ER, Toliver-Kinsky T: Mechanisms of the inflammatory response. Best Pract Res Clin Anaesthesiol 2004, 18:385-405.

48. Balan V, Nelson DR, Sulkowski MS, Everson GT, Lambiase LR, Wiesner RH, Dickson RC, Garcia A, Moore PA, Yu R, Subramanian GM: Modulation of interferon-specific gene expression by albumin-interferon-alpha in interferon-alpha-experienced patients with chronic hepatitis $C$. Antivir Ther 2006, 11:901-908.

49. Filmus J: Glypicans in growth control and cancer. Glycobiology 2001, 11:19R-23R

50. Spear PG: Herpes simplex virus: receptors and ligands for cell entry. Cell Microbiol 2004, 6:401-410.

51. Shieh MT, WuDunn D, Montgomery RI, Esko JD, Spear PG: Cell surface receptors for herpes simplex virus are heparan sulfate proteoglycans. J Cell Biol 1992, 116:1273-1281.

52. Barber: Host defense, viruses and apoptosis. 2001, 8. Publ Online 22 Febr 2001 doi:101038sjcdd4400823.

53. Cuff S, Ruby J: Evasion of apoptosis by DNA viruses. Immunol Cell Biol 1996, 74:527-537.

54. Lagunoff M, Carroll PA: Inhibition of apoptosis by the gamma-herpesviruses. Int Rev Immunol 2003, 22:373-399.

55. Jerome KR, Fox R, Chen Z, Sears AE, Lee H, Corey L: Herpes simplex virus inhibits apoptosis through the action of two genes, Us5 and Us3. J Virol 1999, 73:8950-8957

56. Chu JJH, Ng ML: The mechanism of cell death during West Nile virus infection is dependent on initial infectious dose. J Gen Virol 2003, 84:3305-3314

57. Kleinschmidt MC, Michaelis M, Ogbomo H, Doerr H-W, Cinatl J: Inhibition of apoptosis prevents West Nile virus induced cell death. BMC Microbiol 2007, 7:49.

58. Dégremont L, Bédier E, Soletchnik P, Ropert M, Huvet A, Moal J, Samain J-F, Boudry P: Relative importance of family, site, and field placement timing on survival, growth, and yield of hatchery-produced Pacific oyster spat (Crassostrea gigas). Aquaculture 2005, 249:213-229.

59. Schikorski D, Renault T, Saulnier D, Faury N, Moreau P, Pépin J-F: Experimental infection of Pacific oyster Crassostrea gigas spat by ostreid herpesvirus 1: demonstration of oyster spat susceptibility. Vet Res 2011, 42:27.

60. Barbosa-Solomieu V, Moissec L, Vazquez-Juarez R, Ascencio-Valle F, Renault T: Diagnosis of ostreid herpesvirus 1 in fixed paraffin-embedded archival samples using PCR and in situ hybridization. J Virol Methods 2004, 119(2):65-72. 
61. Pepin JF, Riou A, Renault T: Rapid and sensitive detection of ostreid herpesvirus 1 in oyster samples by real-time PCR. J Virol Methods 2008, 149:269-276.

62. De Decker S, Reynaud Y, Saulnier D: First molecular evidence of cross-species induction of metalloprotease gene expression in Vibrio strains pathogenic for Pacific oyster Crassostrea gigas involving a quorum sensing system. Aquaculture 2013, 392-395:1-7.

63. Pfaffl MW: A new mathematical model for relative quantification in real-time RT-PCR. Nucleic Acids Res 2001, 29:e45.

doi:10.1186/1471-2164-15-580

Cite this article as: Segarra et al:: Dual transcriptomics of virus-host interactions: comparing two Pacific oyster families presenting contrasted susceptibility to ostreid herpesvirus 1. BMC Genomics 2014 15:580.

\section{Submit your next manuscript to BioMed Central and take full advantage of:}

- Convenient online submission

- Thorough peer review

- No space constraints or color figure charges

- Immediate publication on acceptance

- Inclusion in PubMed, CAS, Scopus and Google Scholar

- Research which is freely available for redistribution 